\title{
Taxonomic studies on species belonging to subgenus Eutricharaea Thomson of the genus Megachile (Hymenoptera: Megachilidae)
}

\author{
Priyanka Kumari* \\ High Altitude Regional Centre, Zoological Survey of India, Solan-17321 (Himachal), India \\ Neelima R. Kumar \\ Department of Zoology, Panjab University, Chandigarh-160014, India \\ Avtar K. Sidhu \\ High Altitude Regional Centre, Zoological Survey of India, Solan-173211 (Himachal), India \\ Kailash Chandra \\ Zoological Survey of India, Kolkata- 700053, India \\ *Corresponding author. E-mail: priyanka.dadhwal.chandel@gmail.com

\begin{abstract}
Solitary bees belonging to genus Megachile are important pollinators very crucial for the wellbeing of the ecosystem. Large scale surveying will return a wealth of spatio-temporal species data which is critical for systematics, taxonomy and conservation of biodiversity. Detailed taxonomic characterization of solitary bee species belonging to subgenus Eutricharaea collected from the Sutlej basin of Indian northern plains is being described. A total of four species viz. Megachile hera Bingham, M. femorata Smith, M. vera Cameron and $M$. argentata Cameron belonging to subgenus Eutricharaea with 18 examples were studied. Detailed morphological descriptions, zoogeographic records, specimen examined, floral associations with illustrations and morphological measurements have been provided. Various areas finalised from different parts of Sutlej basin of northern plains were surveyed for the first time for the documentation of Megachile fauna. Hence, all these four species are first records for the studied area.
\end{abstract}

Keywords: Collections, Eutricharaea, Genitalic structures, Megachile, Sutlej basin

\section{Article Info \\ https://doi.org/ \\ 10.31018/jans.v11i3.2125 \\ Received: June 10, 2019 \\ Revised: July 11, 2019 \\ Accepted: August 19, 2019}

\section{How to Cite}

Kumari, P. et al. (2019). Taxonomic studies on species belonging to subgenus Eutricharaea Thomson of the genus Megachile (Hymenoptera: Megachilidae). Journal of Applied and Natural Science, 11(3): 612- 618 https://doi.org/ 10.31018/jans.v11i3.2125

\section{INTRODUCTION}

Subgenus Eutricharaea falls under genus Megachile, tribe Megachilini and family Apidae. There are over 1500 species worldwide (Weldmann, 2009) under 50 genera. In India a total of 75 species have been reported from tribe Megachilini (Gupta, 1999) of which 16 species are reported from genus Megachile. Not much data is available for the subgenus Eutricharaea. The bees included in this subgenus are short megachilines. Megachilini are important ecologically because of the role they play in pollination of various crops and wild vegetation (Michener, 2007). A review of Megachile species belonging to subgenus Eutricharaea has been presented as the study about their zoogeographic distribution, their availability at different places at different times of the season provides an insight about their abundance. They are small bees with cordate abdomen where scopa is present underneath for pollen storage. They are fast flying and energetic bees.

\section{MATERIALS AND METHODS}

The present study which included the documentation, collection, preservation, identification and photography of Megachile bees was done on Sutlej basin of northern plains covering Punjab, parts of Haryana and Chandigarh. The various cities covered were Kapurthala, Ropar, Pathankot, Jalandhar, Talwara, Una, Hoshiarpur, Ludhiana, Amritsar and Kapurthala in Punjab; Yamunanagar and Panipat in Haryana. Collection tours were organised during the years from 2013-2016. The temperature of this basin is very hot in summers and very cold in winters ranging from average $5^{\circ} \mathrm{C}$ to $45^{\circ} \mathrm{C}$. Collections tours were planned keeping the timings of flowering of flora, temperature, rainfall etc. in mind. Megachile bee specimens collected in the field were killed with ethyl acetate vapours and then properly stretched for future studies. Well preserved specimens were studied using keys given by Bingham (1897) and Michener (2000). Adult specimens were photographed with Canon D60 digital camera and morphological measurements were taken with stereozoom binocular with RSM 9 software and Jenoptic camera. Genitalic and sternal slides were photographed with Leica microscope.

\section{RESULTS AND DISCUSSION}

The taxonomically important characters of four 


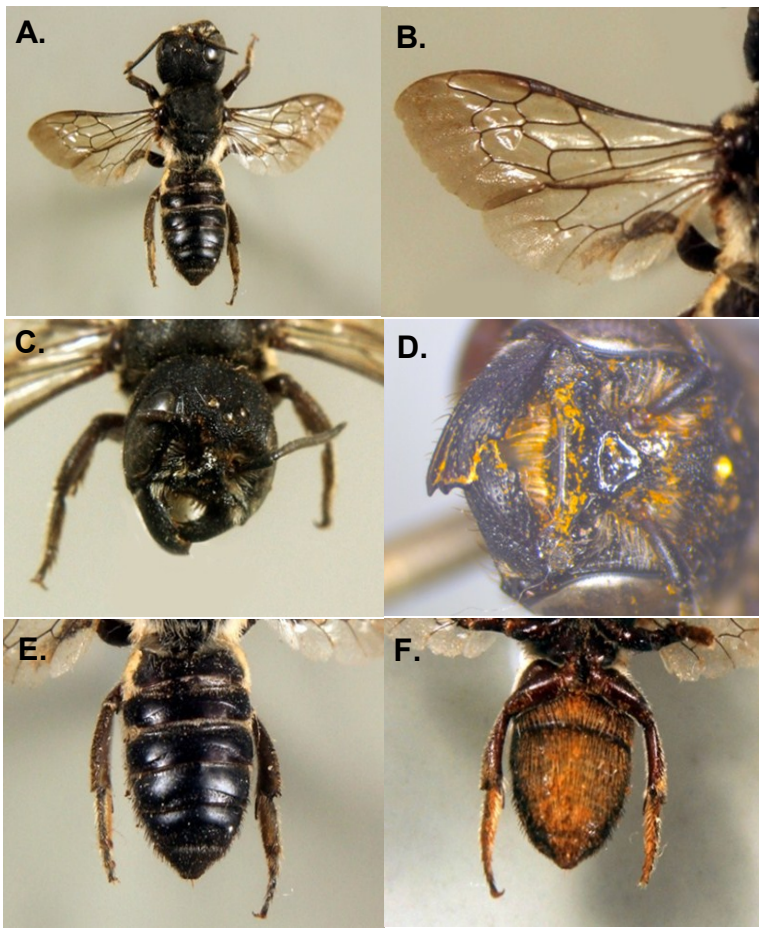

Plate 1. (Figs. a-f). Megachile hera female a). Habitus, dorsal view b). Wings c). Head and Mesosoma, dorsal view d). Mandibles and clypeus e)Metasoma, dorsal view f). Sterna, ventral view

species belonging to subgenus Eutricharaea of genus Megachile Latrielle are being illustrated.

Genus Megachile Latreille: Megachile Latr. 1802. Histoire Naturelle des Fourmis. p.43. Type species: Apis centuncularis Linn. 1758, p. 575.

Anthophora Fabr. 1804, p. 372. Type species: Apis centuncularis Linn.

Subgenus Eutricharaea Thomson: Eutricharaea Thomson 1872, Hym. Scand. Vol. II, p. 288. Type species Apis argentata Fabricius.

Paramegachile Friese 1899, "Die Binnen Europas". Vol. VI, p. 34.

Eutricharaea Mitchell 1937, Trans. Amer. Ent. Vol. 43, p.426.

Eutricharaea Michener 1965, Bull. Amer. Mus. Nat. Hist. Vol. 130, p.206.

Eutricharaea Pasteels 1965, Ann. Mus. R. Afr. Centr., Tervuren Sci. Zool. Vol. 137, p. 194.

Females have quadridentate mandibles with incomplete cutting edges in second interspace, complete cutting edge in third interspace, inner angle acute; first flagellar segment shorter than second; sixth tergum concave in profile; basal spicule in claws; suberect hairs present on surface; pubescent bands present on sterna, sixth sternum without bare rim.

Males have 3 or 4 dentate mandibles, inferior basal projections may or may not be present; first flagellar segment shorter than second; hairy first coxae, with or without apical spine; movable middle tibial spur; middle claws a little asymmetrical;

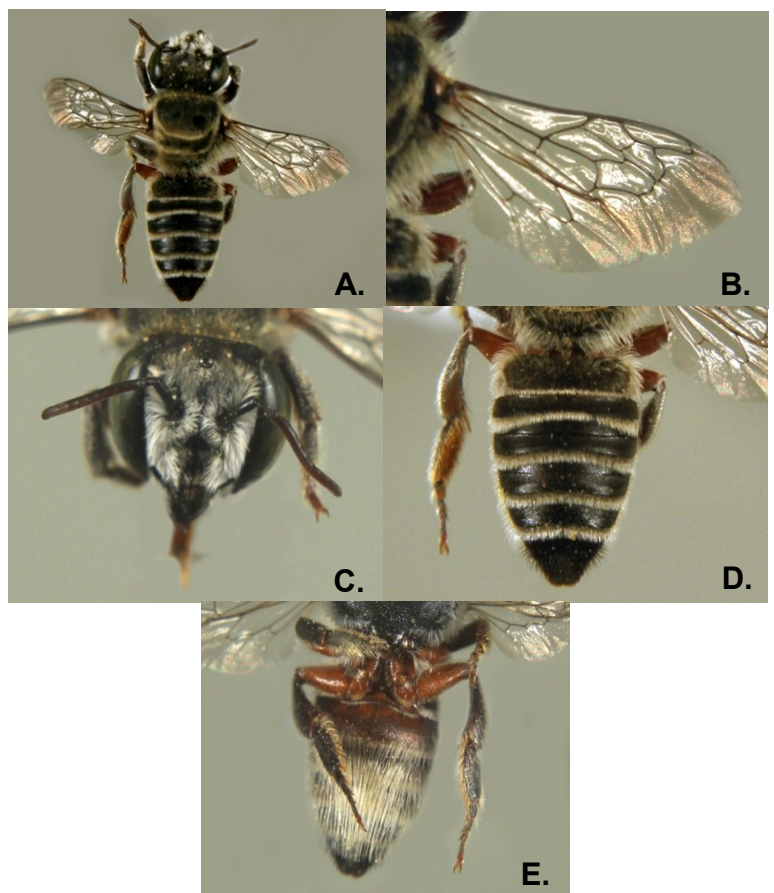

Plate 2. (Figs. a-e). Megachile femorata female a). Habitus, dorsal view b). Wings c). Head and Mesosoma, dorsal view d). Metasoma, dorsal view e). Sterna, ventral view

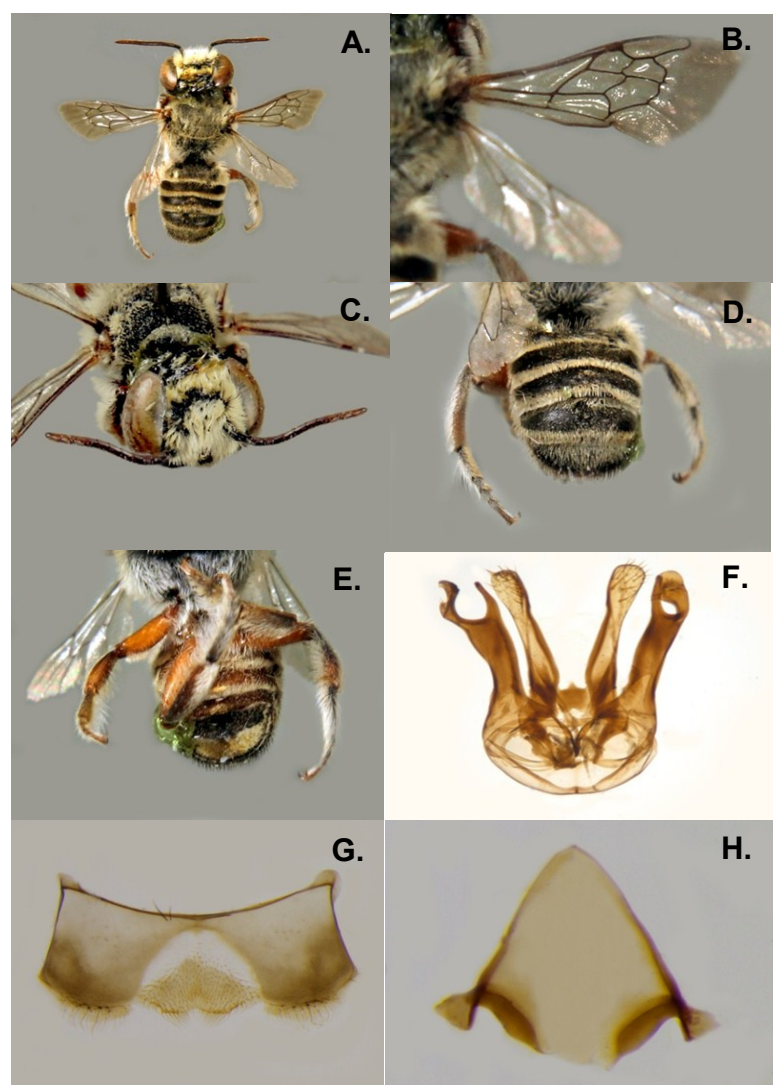

Plate 3 (Figs. a-h). Megachile femorata male a). Habitus, dorsal view b). Wings c). Head and Mesosoma, dorsal view d). Metasoma, dorsal view e) Sterna , ventral view f). Genitalia g). Sternum 6 h.) Sternum 8 
middle and hind basi tarsi half of tibiae; tergum with middle emargination, punctate closely; four exposed sterna; fifth sternum with sternites not or weakly defined; eighth usually short without hairs along lateral margins.

\section{Key to species of subgenus Eutricharaea} Thomson

Scopal brisltles golden on sterna 3-5, clypeal margin with dents; smooth supraclypeus, swollen in profile..........................Megachile hera Bingham - Scopal bristles white on sterna 3-.....2 Mid and hind femora dull orange red in colour................. 3

All legs black........................... 4

Abdomen cordate in females, pale white pubescence; tergum 6 with 7-9 minute spines on each side of medial invagination, pubescence pale yellow in males, gonostylii bifurcated with hairs..............Megachile femorata Smith - Fore tarsi testaceous; gonostylii bifurcated, apices plane without any hairs..............Megachile vera Cameron

Abdomen broad, parallel sided, smooth rounded posterior margin, without spines...........Megachile argentata Cameron

\section{Megachile hera Bingham}

Megachile hera Bingham 1897, Fauna of Brit. Ind. Vol. I, p. 489

Megachile punjabensis Cameron, 1907b. Jour. Bomb. Nat. Hist. Soc. Vol. XVIII, pp. 130-136 Megachile bombayensis Cameron, 1910, Jour. Bomb. Nat. Hist. Soc. Vol. XIX, pp. 131-135.

Female (Plate 1, Figs. a-f)

Diagnosis: Integument is black; antennal flagellum dark brown, base of claws and tarsal apices with redness; white tibial spur. Pubescence is yellowish white on posterior margin of scutellum and lateral extremeties of terga 2-4; lateral fringe over the tarsi and terga with yellowish brown down on ventral side; scopal hairs on sterna 3-5 with golden brown tinge.

Head: Medio longitudinally impunctate line present on clypeus, apical margin outcurved with many small projections, punctate closely; supraclypeus elevated a little above the clypeus, dense pubescence on the sides of clypeus; vertex with black down impregnated with sparse red hue, in bent margin; lateral ocelli close to vertex than to eye and to each other; narrowed genae at apex.

Mesosoma: Scutum with small, dispersed black hairs anteriorly and on lateral margins; scutellum with fasciae at base of scutum; mesepisterna punctured heavily and closely; lateral sides of thorax pubescent and densely hairy; hyaline wings; veins and tegulae brownish red; unmodified and simple legs, apices of tarsi of mid legs excavated, apices of tarsi of hind legs $3 / 4$ th of tibiae.

Metasoma: Soft, small hairs present on first tergum; second and third tergum with shallow grooves along gradull; depressed tergal margins;

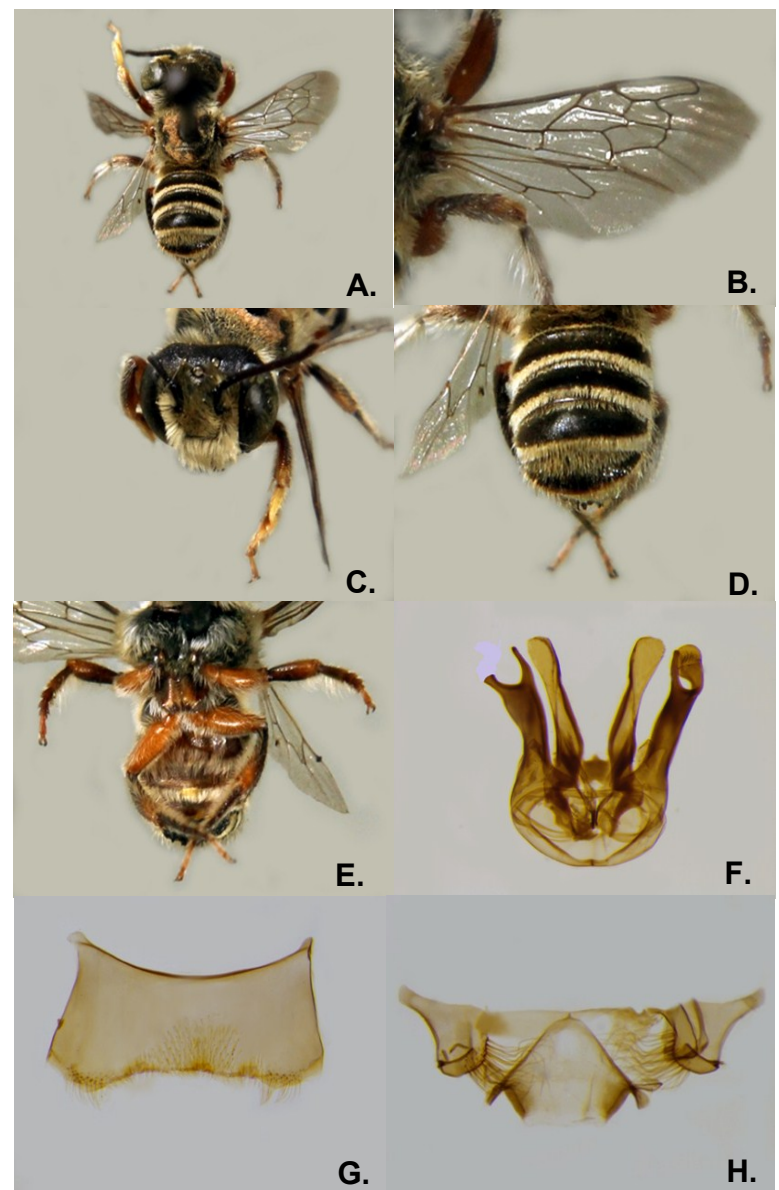

Plate 4 (Figs. a-h). Megachile vera male a). Habitus, dorsal view b). Wings c). Head and Mesosoma, dorsal view d). Metasoma, dorsal view e) Sterna, ventral view f). Genitalia g). Sternum 6 h.) Sternum 8.

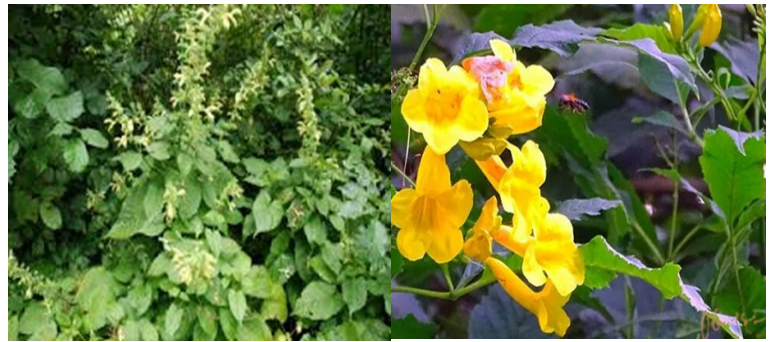

Salvia glutonisa (L. ) Campanula latifolia L.

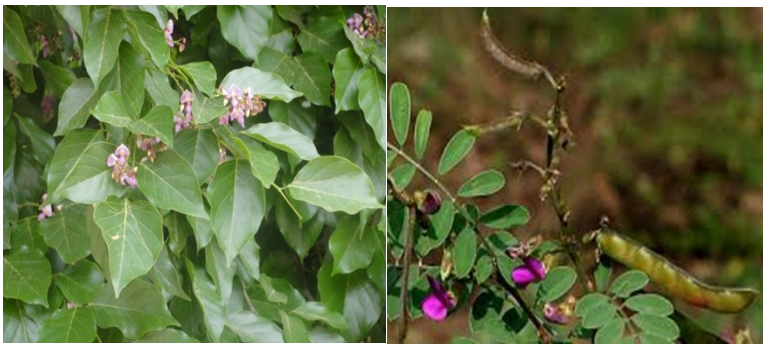

Milletia pinnata (L.)

Tephrosia hamiltonni J.

Plate I. Observed floral associations of Megachile hera Bingham. 
Kumari, P. et al. / J. Appl. \& Nat. Sci. 11(3): 612- 618 (2019)
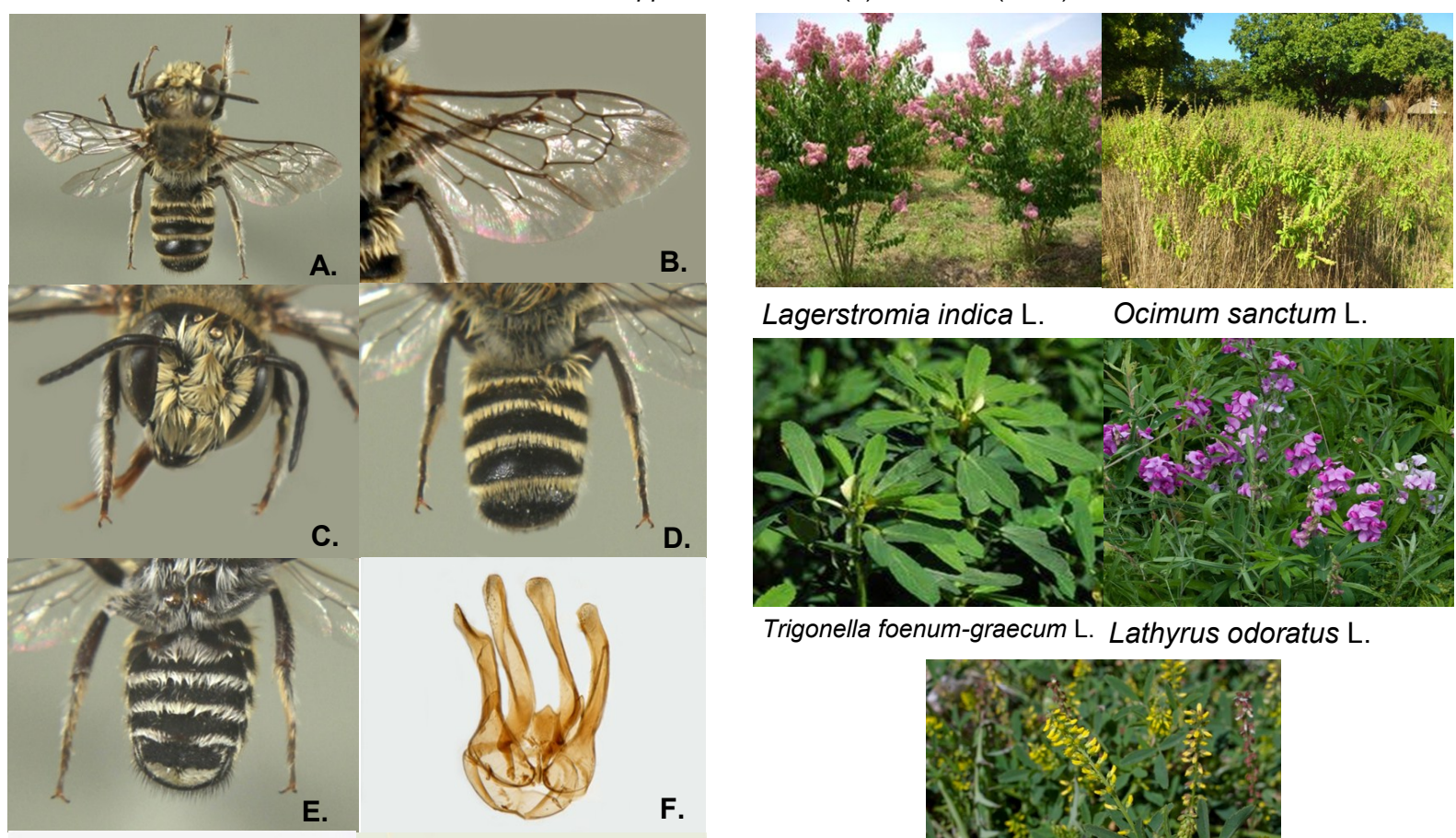

Trigonella foenum-graecum L. Lathyrus odoratus L.

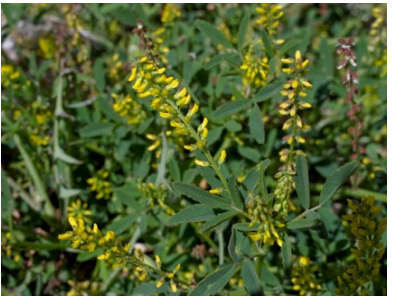

Foeniculum vulgare Mill.

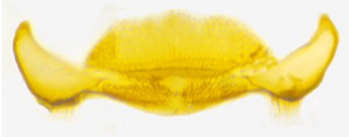

G.

H.

Plate 5 (Figs. a-h). Megachile argentata male a). Habitus, dorsal view b). Wings c). Head and Mesosoma, dorsal view d). Metasoma, dorsal view e). Sterna , ventral view f) Genitalia g). Sternum 6 h). Sternum 8

fine and sparse pregradular punctures; fine and close postgradular punctures on terga 1-3, sparse postgradular punctures on terga 4-5; lateral margins of sterna with brownish red hue; apical margins of sterna with redness; sternum $6^{\text {th }}$ without any fringe at apex.

Zoogeographic record: Kapurthala $\left(31^{\circ} 22^{\prime}\right.$ 47.9964" N, $75^{\circ} 22^{\prime} 47.9892^{\prime \prime}$ E), Ropar (30.9659 $\left.\mathrm{N}, 76.5230^{\circ} \mathrm{E}\right)$, Pathankot $\left(32.2643^{\circ} \mathrm{N}, 75.6421^{\circ}\right.$ E).

Specimen examined: 1\%, 12 April, 2014, Kapurthala; 2 , 3 May, 2014, Ropar; 19 , 7April, 2015, Pathankot.

Floral associations: (Plate I) Lamiaceae: Salvia glutonisa (L.); Campanulaceae: Campanula latifolia L.; Fabaceae: Milletia pinnata (L.), Tephrosia hamiltonni J. Plate I illustrates the flora on which Megachile hera Bingham was collected during the collection surveys.

Remarks: Its original description dates back to Bingham in 1897, later it was renamed and described as M. punjabensis by Cameron in 1904.
Plate II. Observed floral associations of Megachile femorata Smith.

Cameron in 1908 again upgraded its synonymy by naming it as $M$. bombayensis. Later, it was given its original description as $M$. hera by Michener (2000). Its distribution records are from Burma, South China and northern India.

Megachile femorata Smith: Megachile femorata Smith 1879, Descriptions of New Species of Hymenoptera in the Collection of the British Museum. Vol. V, p. 68

Megachile femorata Dalla Torre 1894a, Cat. Hym. Vol. X., p. 430.

Megachile femorata Bingham 1897, Fauna of Brit. Ind. Vol. I, p. 488.

Female (Plate 2, Figs. a-e)

Diagnosis: Integument black; mid and hind coxae, trochanter and femora entirely dull orange, tibial spur pale; base of claws and apex of tarsus 5 fulvous; testaceous tegulae. Pubescence is white on face, legs, basal tergal fasciae, sternal fasciae and scopal bristles; yellowish white on thorax separating scutum from scutellum, tarsal fringe golden.

Head: Slightly convex clypeus, punctate, smooth apical margin; supraclypeus feebly elevated, punctate closely; paraocular area declivous below the antennal margins, punctured closely; vertex convex slightly, punctured closely, incurved margin; lateral ocelli equidistant from eyes; width of eye more than the width of gena; incarinate hypostomal margin, pubesecent; mandibles four 
dentate with complete cutting edges.

Mesosoma: Scutum elevated, punctured heavily, linear parapsidal lines clear, pubescence long and dense on sides, light on disc; pronotal lobe swollen, distinct, carinate, punctate; mesepisterna punctate, pubescent; scutellum broadly curved at posterior margin, punctured finely and closely; lateral extensions of metanotum excavated and not depressed, pubescent densely; propodeal triangle distinct with posterior margins recurved, rough triangle with punctured sides, acute apex; legs simple without modifications, claws with two bristles at base.

Metasoma: Subcarinate tergal concavity, linear vertical fold, smooth and shining concavity, minute punctures, convex post gradular area, punctate closely and minutely, fasciate apical margin; linear and complete graduli on terga $2-5$, partially exposed pregradular area, grooved shallowly, punctured closely; width of tergum $6^{\text {th }}$ greater than length, profile straight; first sternum convex in middle, declivous at sides, sterna 2-5 nicely covered with scopal hairs, sternum $6^{\text {th }}$ transversely depressed and covered with scopal hairs.

Male (Plate 3, Figs. a-h)

Diagnosis: Integument black, apex of fore tibiae, tarsi yellowish; sterna 1-4, legs with redness; entire face covered with white pubescence.

Head- Clypeus slightly raised, pubescent densely, apically outcurved, medially invaginated lateral ocelli equidistant to occipital margin; mandibles 3 dentate.

Mesosoma: Scutum outcurved, covered with pale yellow pubescence; wings hyaline and subfuscescent; first and second labial palpi equal in length; fore coxae flat, basitarsi flattened and excavated; claws with subapical teeth; mid and hind legs simple;

Metasoma: Abdomen short, cordate; apical fasciae on terga 1-5 with pale white pubescence; terga $7^{\text {th }}$ rounded and incised in middle with teeth along the margin; 4 sterna exposed with hairs on last posterior margin.

External genitalia: Gonocoxites are broad, elongated and outgrown; gonostylus is bifurcated deeply at the apex with inner arm slender and outer arm broad. Penis valves are parallel, slightly increasing in width at apex. Penis valves and gonostylus are covered with short hairs.

Zoogeographic record: Jalandhar $\left(31.3260^{\circ} \mathrm{N}\right.$, $\left.75.5762^{\circ} \mathrm{E}\right), \quad$ Yamunanagar $\left(30.1290^{\circ} \mathrm{N}\right.$, $\left.77.2674^{\circ} \mathrm{E}\right)$, Talwara $\left(31.9311^{\circ} \mathrm{N}, 75.8941^{\circ} \mathrm{E}\right)$, Una $\left(31.4684^{\circ} \mathrm{N}, 76.2708^{\circ} \mathrm{E}\right)$.

Specimen examined: $2 \hat{\jmath}, 10$ September 2013, Jalandhar; 1, 14 September 2013, Yamunanagar; 3 q, 2 October 2013, Talwara; $1 \hat{\jmath}$, 9 September, 2014, Una; 1, 18 September, 2014, Una.

Floral preference: (Plate II) Lythracea: Lagerstromia indica L.; Lamiaceae: Ocimum sanctum L.; Fabaceae: Trigonella foenum-graecum L., Lathy-

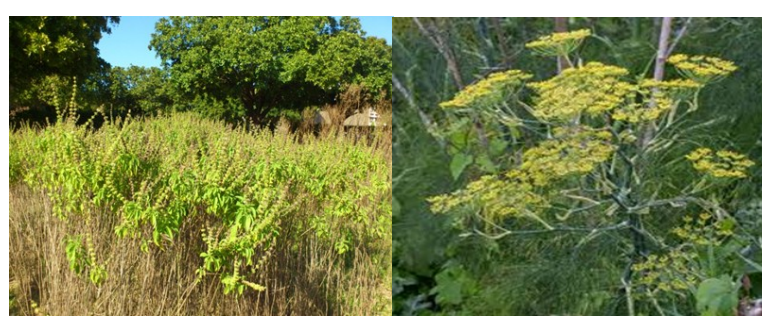

Ocimum sanctum $\mathrm{L}$. Foeniculum vulgare Mill.

PLATE III: Observed floral associations of Megachile vera Nurse

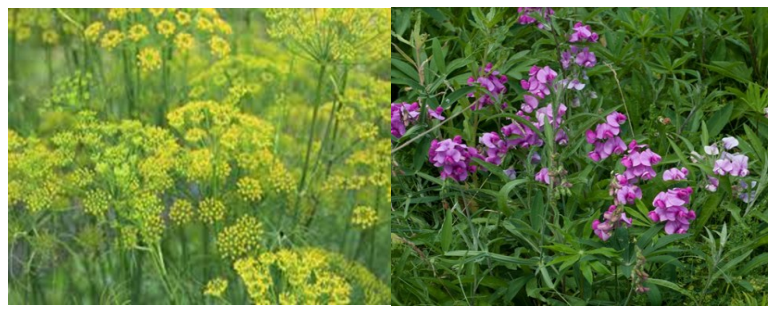

Foeniculum vulgare Mill. Lathyrus odoratus L.

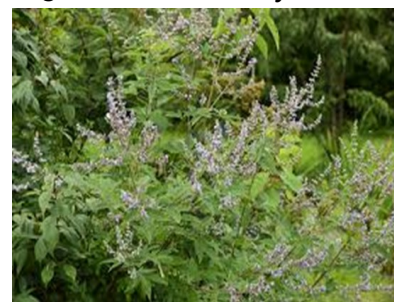

Vitex negundo L.

Plate IV. Observed floral associations of Megachile argentata Cameron.

rus odoratus L., Melilotus indica (L.). Plate II illustrates the flora on which Megachile femorata Smith was collected during the collection surveys.

Remarks: Smith (1879) described this as a new species $M$. femorata. It was redescribed by Dalla Torre (1894) and Bingham (1897). Its distribution records are from Central and Northern India including Bombay, Kolkata, Ahmedabad, Allahabad.

Megachile vera Nurse: Megachile vera Nurse 1901, Jour. Asiatic Soc. Beng. Vol. LXX, p. 150.

Male (Plate 4, Figs. a-h)

Diagnosis: Black integument; flagellum of antennae, tarsus 5 apex, base of claws, tegulae margins, apical margins of sterna 2-5 with redness, tibial spur pale, femora of all terga orange red. Pubescence is white all over the clypeus, supraclypeus, paraocular area, vertex, genae, thorax, apical margins of terga 1-5, sternal margins and legs; tergum 5 discal hairs black; tarsi with pale yellow hairs.

Head: Width of face more than its length, clypeal margin produced anteriorly with three fine evaginations at centre; antennal sockets equidistant to eye and clypeus and nearly equidistant to ocellus and each other; lateral ocelli closer to occipital margin than to eye; width of eyes half of its length, genae narrow at apex; vertex margin inbent heavily; mandibles tridentate with sharp cutting edges; 
first segment of labial palpi longer than second. Mesosoma: Scutum flat, pubescent with grey hairs; scutellum narrow, flat; front coxae with short spine; femora flattened slightly, tibiae parallel sided, mid and hind legs simple and unmodified; all legs with reddish orange tinge.

Metasoma: Metanotum parallel sided, lateral extensions not depressed; all terga almost of same width, grooved lightly at graduli, punctured nicely and closely; thin and full tergal fasciae, basal tergal fasciae with white setae; tergum $6^{\text {th }}$ transverse carina spinose.

External genitalia: Gonocoxites are wide, outgrown and produced into bifurcated gonostylus. Penis valves are narrow at the base and bulb shaped at the apex. They are not covered with hairs.

Zoogeographic record: Hoshiarpur $\left(31.5143^{\circ} \mathrm{N}\right.$, $\left.75.9115^{\circ} \mathrm{E}\right)$, Ludhiana $\left(30.9010^{\circ} \mathrm{N}, 75.8573^{\circ} \mathrm{E}\right)$, Panipat $\left(29.3909^{\circ} \mathrm{N}, 76.9635^{\circ} \mathrm{E}\right)$.

Specimen examined: $1 \hat{\jmath}, 25$ September, 2014, Hoshiarpur; $1 \hat{\jmath}, 17$ October, 2015, Ludhiana; $1 \hat{\jmath}$, 22 October, 2015, Panipat; $1 \delta$, 23 October, 2015, Ludhiana.

Floral associations: (Plate III) Lamiaceae: Ocimum sanctum L.; Apiaceae: Foeniculum vulgare Mill. .). Plate III illustrates the flora on which Megachile vera Nurse was collected during the collection surveys.

Remarks- Nurse (1901) described it as new species in Journal of Asiatic Society of Bengal. Its distribution records are from northwest India, south China, Burma, Bhutan.

Megachile argentata Cameron: Megachile argentata Cameron 1910, Jour, Bomb. Nat. Hist. Soc. Vol. XIX, p.137.

Male (Plate 5, Figs. a-h)

Diagnosis: Integument black, tip of teeth of mandible, tarsus 5 apex, base of claws fuscous; white pubescence on mandible base, clypeus, gena, face, thorax, tibiae, apical margins of tergum and basal fasciae of sterna.

Head: Clypeus elevated, rounded, incurved, smooth line in between, straight apical margin, shallow incurved area present on the sides; supraclypeus convex, punctured finely; paraocular area declivous below level of antennae, punctate heavily; convex subocellar area, punctiform and sculptured; margins of vertex straight, punctured; lateral ocelli closer to each other than to the occipital margins; maximum width of genae less than the width of eye, protruding above; hypostomal area elevated; mandibles tridentate, robust and broad.

Mesosoma: Scutum swollen, elevated anteriorly, punctate closely, parapsidal lines visible; pronotal lobes carinate, swollen, punctures close; mesepisterna punctured finely, pubescence sparse; metepisterna not modified; lateral margin of propodeal triangle recurved laterally, acute apex, median length longer than breadth; wings hyaline with black veins; tegulae sparsely punctate, testaceous; unmodified forelegs, short spine on tibiae, tarsi excavated, two bristles on claws, hind metatarsi shorter in length than corresponding tibiae.

Metasoma: Subcarinate margins, shining and smooth, punctured closely, pubescent medially with dull white hairs on basal margins of terga 2-5; postgradular area convex, grooved closely and narrowly along terga 2-3, punctured with fasciae; width of tergum 6 more than the length, spinose, distribution of spines variable; parallel profile of metasoma; sterna depressed in middle, sterna 2-5 visible.

External genitalia: Gonocoxites and penis valves of same breadth; gonostylus club shaped, without hairs. Penis valves swollen at apex. Apodemes of penis valves thick and short in gonobase.

Zoogeographic record: Amritsar $\left(31.6340^{\circ} \mathrm{N}\right.$, $\left.74.8723^{\circ} \mathrm{E}\right)$, Kapurthala $\left(31.3715^{\circ} \mathrm{N}, 75.3937^{\circ} \mathrm{E}\right)$ Specimen examined: 1 $\hat{\jmath}, 1$ September, 2013, Amritsar; 2స, 23 September, 2015, Kapurthala; $1 \hat{0}, 1$ October, 2015, Kapurthala.

Floral associations: (Plate IV) Apiaceae: Foeniculum vulgare Mill.; Fabaceae: Lathyrus odoratus L.; Lamiaceae: Vitex negundo L. Plate IV illustrates the flora on which Megachile argentata Cameron was collected during the collection surveys.

Remarks: Cameron (1910) described it as $M$. argentata. Distribution records are from Nepal, Bangladesh, and northern India.

\section{DISCUSSION}

Extensive surveys of selected areas are very important for the taxonomic documentation. Gupta (1999) surveyed north western India but Sutlej basin of northern plains was surveyed for the first time in the present study. Michener (2007) gave the detailed taxonomic account of bees covering the whole world.

\section{Conclusion}

There has not been much extensive surveying of the solitary bees from Sutlej basin of northern plains. The areas mentioned above have been surveyed for the first time. All the four species are first records for the studied area.

\section{ACKNOWLEDGEMENTS}

Author acknowledges the support given by Director, ZSI for the accomplishment of this work.

\section{REFERENCES}

1. Bingham, C.T. (1897). In: The Fauna of British India (W.T. Blandform ed.) Taylor and Francis, London CCIS, $579 \mathrm{pp}$.

2. Cameron, P. (1904). On some new species of Hymenoptera from Northern India. Ann. of Nat. Hist. 13: 177-303. 
3. Cameron, P. (1908). A new species of Megachile from India. Entomo. 41: 88.

4. Cameron, P. (1910). Some undescribed bees and wasps. Jour. of Bomb. Nat.I His. Soc., 19: 131-170.

5. Dalla Torre, C.G. de (1894). Catalogues Hymenoptarorum. Leipz. 16(10): 374-497.

6. Gupta, R. K. (1999). Taxonomic Studies on the Megachilidae of North-Western India. Scientific Publishers, Jodhpur (India), 294 pp.

7. Michener, C.D. (2000). The Bees of the World. The Johns Hopkins Universitiy Press, Baltimore, USA, 913pp.

8. Michener, C.D. (2007). The Bees of the World. The
Johns Hopkins Universitiy Press, Baltimore, USA 972pp.

9. Nurse, P. (1901). Fauna of bees collected in British Museum .Jour. of the Asia. Soc. of Beng. 70: 150.

10.Smith, F. (1879). Descriptions of new species of Hymenoptera in the Collection of the British Museum, London: British Museum, $240 \mathrm{pp}$.

11.Weldmann, S, Wappler, T; Engel and Michael S. (2009). "Direct and indirect fossil records of megachilid bees from the Paleogene of Central Europe (Hymenoptera: Megachilidae)". Naturwissenschaften. 96 (6):703-712. 